be little doubt that this is in part only a manifestation of the general tendency for increasing loss to occur from diseases and other causes when a population is allowed to grow very rapidly without the coincident development of an efficient 'public health' service. The major causes must probably, however, be looked for in other directions, since the great increase in the poultry population between 1918 and 1928 was not accompanied by any serious rise of mortality. Some are inclined to look upon the present troubles of the industry as the harvest of seed sown in that earlier boom period, when possibly the industry expanded faster than its capacity to supply itself with sound breeding stock ; others place the major blame upon excessive resort to 'intensive' methods-too much science! Still others find a partial explanation in the all too easy dissemination of stock from uncontrolled breeding centres. Wherever the cause may lie, be it in breeding, incubation, management, disease control, or any other part of the field of the poultryman's activities, the need for a combined attack upon the problem is now clamant. Practice alone is unlikely to prove capable of finding a solution; to the scientific investigator, a vast field of service is open in which the rewards, both to the individual and to the nation, are great and certain.

C. C.

\title{
$\mathrm{Obituary}$
}

\section{Prof. R. C. J. Howland}

$\mathrm{R}^{\mathrm{A}}$ AYMOND CLARENCE JAMES HOWLAND was born in Fulham on June 5, 1896, and was educated at Latymer Upper School, Hammersmith (1907-15). In December 1914 he won an open scholarship at Emmanuel College, Cam. bridge, and went into residence in October 1915. After two terms, an attempt to join the O.T.C. having failed on account of defective eyesight, he nevertheless succeeded in enlisting as a gunner in the R.G.A. in March 1916, went to France and served through the rest of the War, returning to Cambridge at the beginning of the Easter term 1919. Although he obtained a first class in Part I of the Mathematical Tripos and was a wrangler in 1920, the handicap due to the interruption of his studies by the War prevented him from taking Schedule B, and debarred him from opportunities which should normally have been open to one of his mathematical ability. In consequence, he went down from Cambridge after taking his degree in 1920 and spent a year in school-teaching at Berkhamsted.

While in Cambridge, however, Howland had prepared for the London external degree, and took his B.Sc. in 1921 with first class honours; this was followed later by the M.Se. (1922) and by the D.Sc. (1930).

Fortunately, the openings not available to him in Cambridge were found elsewhere, and, in September 1921, Howland was appointed lecturer at the City and Guilds Engineering College, where he remained for two years. It was there, working under the influence of Prof. H. Levy, that he completed his first piece of mathematical research on "Vortex Motion behind a Circular Cylinder", published in the Journal of the Royal Aeronautical Society (1925). His first work to be actually published, however, was a paper on "Transverse Oscillations in Girders" (Institution of Civil Engineers, 1924).

By this time, Howland had obtained (October 1923) a senior lectureship at University College, London, where, although more specially in charge of the teaching to engineering students, he shared in the general work of the Mathematics Department. That he found the atmosphere congenial is shown by the fact that, during the eight years he was at University College, he produced no less than eleven papers, some of outstanding importance.

Howland's scientific interests were alnost exclusively directed to problems of classical mechanics, particularly hydrodynamies and elasticity, with engineering applications. Several of his papers deal with rotating shafts, a subject to which he made serious contributions. Here and there we find papers, for example, on determinantal equations and on harmonic and biharmonic periodic functions, which prove that his abilities would have found scope equally on the side of pure mathematics. The work for which he will be best remembered, however, is his solution for an elastic strip of finite width with one or more circular holes, to which he devoted a series of papers in the Transactions and Proceedings of the Royal Society, either alone or with co-workers. His last paper on this subject was published in 1935 , but the fundamental step, namely, the discovery that he could evaluate the troublesome double integrals occurring in the investigation by changing the order of integration, will be found in the first paper of the set (Proc. Roy. Soc., A, 124; 1929).

Shortly after publishing this, Howland was appointed (October 193I) to the chair of mathematics at University College, Southampton. There he threw himself into the work with his accustomed energy. He had the rare gift of inspiring others to do research, and when he died he had developed a flourishing mathematical school, which he hoped would deal successfully with the problems of local industries, such as shipbuilding and aircraft construction. He was taken ill somewhat suddenly, while travelling in Wales, and died on August 16 of this year. His premature death at the age of forty years not only is a cruel blow to his family 
and his many friends, but also deprives modern engineering of one of its most able and sympathetic mathematical helpers, one who would undoubtedly have made further notable advances in the science of applied mechanics.

As a man, Howland was of a modest and retiring disposition, and it was almost impossible to get him to talk about himself. Behind his reserve, however, lay many wide and human sympathies. In his undergraduate days he was constantly writing both prose and verse, and the choice between literature and mathematics hung for some time in the balance. He was a keen musician and took a full share in musical activities at Southampton. The subjects of various addresses he gave to more popular audiences, on "The Mystery of Number", "Mathematical Wit and Humour" and "Greek Mathematics" are enough to indicate the catholicity of his interests, even in the mathematical field. He married, on November 10 , 1923, Lucy Jane Bullock, and his happy life at home contributed in no small measure to the full development of his scientific powers.

L. N. G. F.

\section{Prof. Alexander Larmor}

Tre death, on October 10, of Alexander Larmor, emeritus professor of natural philosophy at Magee College, Londonderry, has removed one who rendered very valuable services to scientific education in Northern Ireland. His published work, though important, gives a very inadequate idea of his powers of mind and his wide knowledge; his friends and correspondents know that, if he wrote comparatively little, he thought deeply on the subjects which interested him.

Larmor's first paper, published in the Quarterly Journal of Mathematics in 1886, was on the geometrical theory of perspective, and his last. which appeared in 1933, treated of the FitzGerald contraction. These titles indicate the early and the later interests of a man who, at the beginning, studied under Purser and Everett at Queen's College, Belfast, and who took both the Mathematical and the Natural Science Tripos before becoming fellow of Clare College, Cambridge. He began by working at pure geometry; a taste for this subject and great expertness in it were, in his day, imparted to mathematically gifted boys in Irish schools. His most important geometrical paper, contributed to the London Mathematical Society in 1892, was on the contacts of systems of circles. In later years he became absorbed in the fundamental problems of space and time; he kept himself abreast of recent speculations in this region, and brought to them a mind philosophical and acutely critical.

During his tenure of his chair at Londonderry, Larmor gave himself with his whole heart to the work of teaching and administration, and won the regard and gratitude of pupils and colleagues alike. His lectures were admirable, his sympathetic interest in his students unfailing. He took his full share in the politics of the college in a critical period in its history, and helped greatly in the solution of its difficulties.
Larmor was quiet and reserved in manner, but his obvious sincerity and friendliness exercised a strong attraction upon those who had the privilege of knowing him. To younger men, in particular, he was continually showing kindness, and very many will feel for him life-long affection and gratitude.

W. B. M.

\section{Prof. L. M. Ugolini}

WE regret to record the death of Prof. Luigi M. Ugolini, the well-known Italian archæologist, which took place at Bologna recently at the age of forty years.

Luigi Ugolini was born at Bertinoro in Romagna and served in the Alpini during the Great War, being wounded and gaining a bronze medal for valour. After the War he travelled extensively in Europe, Egypt, Roman Africa and the East in the pursuit of his archrological studies. His best known work was connected with the excavation of archæological sites at Fernice and Butrinto in Albania, where he brought to light a number of Groek and Roman antiquities. He had already published three volumes on his researches, and other material was in course of preparation. He was also the author of a work on the prehistoric antiquities of Malta. Recently he had been appointed to a chair in the University of Rome.

\section{Prof. Victor Grignard}

Prof. Ch. Courtor, of Nancy, has given an account (Bull. Soc. Chim., 3, 1433; 1936) of the life and work of Prof. Grignard, Nobel Laureate in 1912, who was best known for his researches on the use of organo-magnesium compounds in synthetic chemistry. Born at Cherbourg in 1871, professor of organic chemistry at Nancy in 1910 and of general chemistry at Lyons in 1919, Grignard carried out a large number of investigations in organic chemistry : Prof. Courtot gives the titles of 163 publications by him and his pupils. During the Great War, he rendered valuable services and was made a member of the Legion of Honour. He was elected an honorary fellow of the Chemical Society in 1920. Shortly before his death on December 13, 1935, Grignard commenced a large treatise on organic chemistry, the first two volumes of which appeared during his lifetime.

We regret to announce the following deaths :

Mr. W. J. Blenheim, American traffic manager of the Western Union Cable system, a pioneer of radio research, on October 29, aged fifty-eight years.

Prof. A. Bömer, emeritus professor of applied chemistry in the University of Münster, and editor of the Zeitschrift für Untersuchung der Lebensmittel, aged sixty-nine years.

Prof. T. M. Lowry, C.B.E., F.R.S., professor of physical chemistry in the University of Cambridge, on November 2, aged sixty-two years.

Dr. Sheffield H. M. Neave, known for his work in 1906-7 on sleeping sickness, on October 24, aged eighty-three years. 